\title{
Uncovering Unused Messaging Tools for Motivating Pro-environmental Behavior
}

\author{
Adrah Parafiniuk \\ Northern Arizona University
}

\begin{abstract}
Environmental knowledge and awareness have small impacts on pro-environmental behavior (PEB). Decades of public information campaigns that inform the public how personal behaviors and consumer choices drive climate change have not changed behavior. Research into motivation for PEB change across disparate fields demonstrates new insights into what motivates behavioral change. This paper provides a review of those literatures, which have not been systematically brought together, in order to generate research questions and propose a new research agenda. The findings indicate the need to test how types of individuals, categorized by what motivates their behaviors, respond to different policy messaging tools.
\end{abstract}

Keywords: PEBs, Behavior Change, Sustainability Psychology, Motivation, Altruism, Rebellion Sustainability, Social Norming, Self-improvement Sustainability

\section{INTRODUCTION}

It has been clearly demonstrated that environmental knowledge and environmental awareness have relatively small impacts on pro-environmental behavior (Finger, 1994; Vicente-Molina et. al, 2013; Bamberg, S., \& Möser, G., 2007). Public campaigns to change behavior have been unsuccessful (Desilver, 2015). Research into motivation for pro-environmental behavior change in the fields of environmental psychology, the psychology of sustainability, game and economic theory, and sustainability communication demonstrate new insights into what motivates behavioral change. This knowledge may help policymakers and social entrepreneurs become more effective communicators and help them drive behavior change.

Human behaviors are fundamentally changing the ecosystems that support human and nonhuman life. Most alarming, the "...human influence on the climate system is clear and growing, with impacts observed on all continents. If left unchecked, climate change will increase the likelihood of severe, pervasive and irreversible impacts for people and ecosystems" (UN IPCC 2014). Human behaviors are also creating regional problems. For example, China's lakes and waterways are experience heavy metal contamination at historic levels due to 30 years of industrialization at unprecedented speed (Xu, Y., Wu, Y., Han, J., \& Li, P., 2017). North America replaced a buffalo dominated ecosystem the size of the Serengeti with monoculture crops. These crops are so dependent on oil based fertilizers that the overuse of these fertilizers has created a hypoxic dead zone in the Gulf of Mexico over 8,700 sq. miles. (Rabotyagov, S. S., Kling, C. L., Gassman, P. W., Rabalais, N. N., \& Turner, R. E., 2014). The Aral Sea 
once the $4^{\text {th }}$ largest saline lake on the planet no longer exists due to over use and irrigation canals that drain the waters (Micklin, P., 2007). On a macro, regional, and local scale, past and current human behavior threatens the ecosystems that support us.

There are multiple drivers of climate change and environmental degradation. Oil based transportation system and coal based energy production produce the vast amount of greenhouse gases (GHGs). Deforestation is driven by growth of population as well as the growth of meat intensive diets and a global economy that will grow or raise food wherever it is most cost-effective to do so. This encourages governments to not incorporate the environmental costs into business agreements. These public policies treat environmental costs as externalities. They are costs that are shared by everyone on the planet as GHGs, air pollution, and land changes that decrease carbon sequestration affects the global atmospheric commons. There is public and scholarly debate on how to mitigate these effects. Top-down approaches have shown success but many countries including the US lack the political will to regulate and implement necessary changes. A grassroots effort supported by local governments and NGOs may have the ability to "trickle up" to policy change when citizen concern and pressure reach a tipping point.

Governments, NGOs, and individuals are attempting to motivate people to change their individual behaviors in order to reduce their individual contributions to carbon emissions that drive climate change. There are myriad changes in behaviors that can have a positive effect on the local environment as well as the global ecosystem but "the current field of pro-environmental research lacks a common behavior categorization scheme" (Gillis, 2016). Some areas that are well studied are:

1. Green energy: especially wind and solar

2. Clean transportation: electric cars, public transportation, self-propelled

3. Waste loop: reduce, recycle, reusable, composting

4. Food systems: less meat, free range, less fertilizer, less pesticides, forest friendly

5. Community involvement: gardening, cleanups, pro-environmental political groups

6. Consumer choices: fair trade, house size, long lasting vs. disposal

The above research areas may refer to individual behaviors and/or public policy domains. This paper analyzes the literature relating to these domains from the individual behavior side, or "pro-environmental behaviors" (PEBs). PEBs are "behavior[s] that consciously seeks to minimize the negative impact of one's actions on the natural and built world (e.g. minimize resource and energy consumption, use of nontoxic substances, reduce waste production)" (Kollmuss and Agyeman, 2002). How policy messaging may shape such behaviors is an important area of research that this paper will synthesize.

\section{Past Success and Current Problems}

\section{Previous PEBs Encouraged Through Government and NGO Outreach}

Several public messaging campaigns have been used successfully to change people's behavior in the United States. The most famous would be the Keep America Beautiful (KAB) Campaign that began in 1953. It was an industry-funded attempt to change individual behavior, specifically littering. It still exists today and has been successful in both changing individual behavior as well as lobbying local and state governments to criminalize littering. While successful, it has been criticized because companies such as Wrigley's, Coca-Cola, Pepsi, Dow Chemicals, Nestlé, and Phillip-Morris supported the shift of responsibility for controlling waste from manufacturer to consumer (Plumer, 2016).

The Ad Council was created in 1942 as the War Advertising Council and has served as a public messaging tool of the Federal Government. It has promoted war bonds, the American Red Cross, Smokey the Bear and campfire safety, the Peace Corps, and the Just Say No Campaign among many others. The Crying Indian PSA, which won two Clio awards, was launched in 1971 and was credited with having a lasting effect on the perception of littering as well as helping to usher in the first Earth Day. The KAB campaign combined with the work of the Ad Council was able to create effective advertisements that motivated people to change their behavior and curb littering in the United States.

Recycling campaigns have also been successful at increasing recycling rates. Places that recycle also tend to create policy that encourages or enforces recycling and this creates a positive feedback loop; the reverse is also true, and cities with low recycling rates tend to enact policies that deter people from 
recycling. In the US, San Francisco recycles $80 \%$ of its waste, whereas Oklahoma City recycles 3\% (EPA, 2014). Currently, the national average recycling and composting rate is $35 \%$.

\section{Positive Change and Negating Pressures}

Energy use is another area that has shown positive change. Most likely due to the use of compact fluorescent light bulbs and light emitting diode bulbs in place of tradition incandescent bulbs (Davis 2017) and more energy efficient appliances, energy use has bucked the 60-year trend of $4 \%$ average annual increases that led to a 10-fold increase in per capita energy use between 1950-2010. Decreases, starting after 2010, demonstrate that educating and promoting more energy effective modifications can be effective. US household energy use per capita decreased by 9\% between 2010-2016 (EIA, 2017). The United States has decreased the amount of carbon dioxide emitted annually. Declines are still extremely small (between 1-2\% annually) but overall they add up to a 14\% decrease from 2005 levels (EIA, 2017). (That trend reversed in 2018 with a slight increase in energy use, but this could be due to extreme weather events.) Decreasing energy use, the increased use of renewable energy, and the transition from coal to natural gas are the main drivers of this transition. In 2016, solar and wind provided $10 \%$ of US household electricity consumption and $15 \%$ of US electricity production (EIA, 2017). The US is annually increasing the percentage of carbon-free electricity produced, but the current pace of implementation is not enough to ameliorate the worst effects of climate change according to the United Nations International Panel on Climate Change report.

Unlike many other developed countries, the US has an additional impediment to motivating PEBs: a counter-science movement and a political group that supports it. The Republican Party controlled all three branches of federal government from 2016-2018, and the legislative and executive branches of 26 states as of 2018. The party's official platform on energy and the environment included the following statements:

"(C)oal is an abundant, clean, affordable, reliable domestic energy resource... Environmentalists are creating an illusion of an environmental crisis... We will likewise forbid the EPA to regulate carbon dioxide... The United Nations' Intergovernmental Panel on Climate Change is a political mechanism, not an unbiased scientific institution. Its unreliability is reflected in its intolerance toward scientists and others who dissent from its orthodoxy. We will evaluate its recommendations accordingly... We reject the agendas of both the Kyoto Protocol and the Paris Agreement... We demand an immediate halt to U.S. funding for the U.N.'s Framework Convention on Climate Change (UNFCCC)" (GOP, 2018). These and other similar words activate frames that automatically invalidate the message that a local government or NGO may be trying to get across (Lakoff, 2010). This situation further complicates any communication aimed at motivating PEBs.

Despite the official Republican Party position on matters related to climate change, and thus PEBs in general, policy decisions and political messaging is still heterogeneous. Municipal and state governments and non-governmental organizations are attempting to motivate PEBs. However, given the dramatically changing information marketplace and the ability for very different political messages to reach the mass public, it is reasonable to reassess what we know about how people respond to such messages and what types of messaging may gain traction.

\section{CHANGING BEHAVIOR}

Environmental awareness was historically seen as the needed ingredient to change behavior, but as knowledge and information about environmental and climate problems has grown there has been little change in the amount of people displaying PEBs (Kollmuss and Agyeman, 2002). Environmental awareness is more likely to be used as a method to deal with environmental fear and anxieties (Finger, 1994). Time and money put into environmental education has not born fruit and the detrimental effects of climate change are beginning to be realized.

The research is clear that the old model of affecting behavioral changes through educating the public about the problem is not effective when it comes to climate change. Climate change is different compared 
to past environmental issues for a number of reasons. It is not as tangible or as visible as a problem like littering. It is hard to understand how an individual can play a part. The scope and scale is beyond humans' natural ability to problem solve (Marshall, 2015). The complexity of climate change is overwhelming: The scope of the problem is so large it covers the entire planet. Every human's behavior is involved in both the problems and the solutions. Humans are not wired to rationally respond to complex statistical risks. Most people focus on the tangible problems that exist in the present. This hyperbolic discounting creates a situation where people are aware of a problem but do not feel the compunction to act (Amaya, D. J. 2017). Clearly, methods outside of traditional public education campaigns are needed.

The researchers have found that individuals who understood what effective steps they could take to initiate change were more likely to participate (Masud et al., 2016). However, experiments that emphasize personal responsibility without a practical step to implement change do not demonstrate significant behavior change. Obradovich and Guenther (2015) demonstrated that emphasizing collective responsibility over personal responsibility statistically increased mitigation behaviors. They proposed that there could be two possible reasons for this: One, due to cognitive dissonance people tried to dissociate with being part of the problem and chose not to act. Two, the difference in behaviors was due to "the difference in construal levels for climate action animated by the personal and collective treatments, which may alter the salient motivations for taking action" (Obradovich and Guenther, 2015). Research has demonstrated that interventions that emphasize both collective responsibility and concrete, practical, personal steps would be demonstrably more effective at increasing the targeted PEB. Framing climate change as a collective action problem with tangible steps for individuals creates a situation that psychologically releases an individual from the full weight or responsibility yet empowers a person to create change. This framing can overcome the shortcomings of traditional public education campaigns.

\section{What Motivates PEBs? The Research so Far Altruistic Motivations}

In researching what motivates people to engage in PEBs the idea of altruism infuses the literature. "(S)elfishness/altruism' names a moral continuum along which the relative weight of self- and otherregarding motives shifts" (Galston, 1993). Regarding sustainability, altruism is the ability to forgo or curtail personal short-term desires for (hopefully) the long-term benefit of everyone. In this sense, altruism is a tool for overcoming collective action problems, and appealing to people's altruistic tendencies may be a useful policy-messaging tool. Reyniers and Bhalla (2013) demonstrate that peer pressure can increase altruistic acts, and while that is helpful, the ultimate goal is a true personal transformation that would shift pressure from external to internal sources, thus leaving individuals to "police" their own behaviors naturally.

A core trait associated with altruistic behavior is compassion; those without compassion are unlikely to engage in altruistic behavior. Wayment and O'Mara (2008) assert: "Identifying with others requires a shift away from self-preoccupation, and such a shift is at the heart of what is called compassion" (p. 159). This ability is also important as an individual acknowledges their similarity to someone less fortunate than themselves. This acknowledgement of similarity leads to a "sense of connection to others, increased compassion" (Wayment and O'Mara 2008, p. 166). Altruistic people do have a tendency to be more involved in movements through events such as demonstrations and altruism is a stronger indicator than personal norms: "...personal norms do not have a direct effect on participation in a demonstration, though altruistic, traditional and openness to change values do" (Stern et al. 1999).

Altruism is rooted in openness to experiences and people. It is also rooted in compassion. It has been argued that compassion, among other attributes is rooted in the quieting of ego (Wayment, Bauer, and Sylaska 2015). It could be argued that the transition to a more sustainable world may be rooted in meditation with a specific goal of letting go of ego. Meditation has the added benefit of decreasing the egotism that has been demonstrated to diminish "personal well-being, health, productivity, and selfesteem" (Bauer and Wayment, 2002).

However one acquires the trait of altruism it is clear that altruistic people are likely to be concerned with the world outside of their personal experience. They are more likely to engage in environmental 
movements and show up for protests (Giugni \& Passy, 2001). They tend to be compassionate to the plight of others and are more willing to change their lives in order to benefit what they believe to be the greater good of humanity (Ozinga, 1999).

While most pro-environmental outreach and marketing encourages individuals to act altruistically, some psychological theories including social exchange theory hypothesize that humans are only willing to be or appear altruistic if the benefits of generosity outweigh the costs. So people must find personal value in common pool resources in order to act. A large part of altruism may be the ability to see the entire human population as the "in-group." If there is no out-group actions that help others are helping everyone including the individual actor. According to value-belief-norm theory, the key to individuals acting altruistically is for them to believe that something of value is threatened (Stern et al., 1999). Acts of altruistic pro-environmental behavior may be individuals working to protect something they value both personally and for humanity in general.

In a different vein of social psychology, Lars Degenhardt finds that "high environmental awareness does not correlate with environmental behaviors." (i.e. behavior that helps ameliorate the current environmental problems) (Degenhardt 2002). His study of lifestyle pioneers (people who have chosen to adopt more "sustainable" lifestyles) demonstrates that people who adopt these lifestyles demonstrate three motives:

1. Consternation as an expression of worrying about oneself and others

2. A Sense of responsibility

3. Giving meaning to life (by taking responsibility for one's actions)

All of these motives are forms of altruistic behavior. The 22 people in Degenhardt's study have moved towards these more sustainable lifestyles because of their empathy. Degenhardt states: "For nearly all interviewed persons, sympathy or sorrow are much more important that worrying about oneself." This empathy allows people to act in a manner that may not always serve their immediate needs but the needs of a greater community.

Degenhardt identifies a number of biographical experiences that have initiated a change in people's worldview that allowed them to become more altruistic: A positive, childhood-made role-model, intensive nature experiences (usually in youth or adolescence), and events (or involvement with groups) in adulthood that inspire change from a "normal" lifestyle. These three important emotional experiences cause people to be more reflective and open to change. This is the most comprehensive work that focuses succinctly on people who choose to live extremely sustainable lifestyle. The people in Degenhardt's work have significantly altered their lifestyles so that everything they do focuses on creating lifestyles that economically, socially, and ecologically sustainable.

Higher levels of altruism and openness to experience, along with sympathy and empathy, appear to indicate a higher likelihood of engaging in PEBs. It appears that meditation and mindfulness are a proven way to increase these traits. It would useful to know if an individual's likelihood to engage in PEBs increases after a program of meditation that focuses on quieting the ego.

\section{Group Normative Motivations}

The normative power of social groups has been demonstrated to have an effect on a wide range of behaviors. People have a tendency to favor whichever behavior they perceive to be in-group behavior over any out-group behavior (Terry, Hogg, and White 2000, p. 72). People try to "better" themselves by conforming to beliefs and actions that are more like those they consider part of their "group." This can be both positive and negative for PEBs (Schultz et al., 2007).

This generality, of self-coercing in order to appear more like our perceived idea of our in-group, appears to apply to pro-environmental behaviors. Xiaodong et. al (2009) demonstrate that the behavior of one's social group (in this case, the neighbors of farmers in an area that was trying to protect pandas) had a demonstrable effect on the actions of the individuals. "In other words, people's re-enrollment intentions can be affected by the re-enrollment decisions of their neighbors and tend to conform to the majority" (Xiaodong, Lupi, Guangming, and Jianguo 2009). When it appears that "our group" favors an action, we, as humans, have a tendency to accept and engage in that action. With the cleaving of political groups in 
the US, it may be more difficult than ever to convince people from a group that does not value environmental issues to engage in PEBs at all.

Correa and Yildirim (2016) demonstrate a broader norming process. People who believe that the normal donation is higher than their usual donation are more likely to increase the amount of their donation: "Our equilibrium analysis reveals that social pressure results in donations that are concentrated around the norm: donors who would anonymously give below the norm increase their donations" (Correa and Yildirim 2016 p. 100). This confirms that people feel a need to be as close as possible to what they consider (or what they are told is) the norm. The study further demonstrates that donors who usually give above the norm are likely to decrease their donation when presented with average donation information.

Though scholarship on behavior norming shows that change is possible, there is a gap in our understanding of how people move from one group towards another after the formative years of young adulthood and what type of messaging or pressure is most effective for different people and over different issue areas.

Norming is pervasive across all societies. It is the process in which humans learn which behavior is acceptable and which is reprehensible. The particular danger of norming for those that are attempting to inform a population of the environmental challenges humanity faces, is that describing widespread antienvironmental behavior can have a boomerang effect. A public service announcement that states: "everyone is littering" actually reinforces that behavior by saying that littering is the norm. The negative behavior must be framed as deviant in order to convince people to decrease or stop the behavior (Cialdini, R. B., Kallgren, C. A., \& Reno, R. R., 1991).

The norming process may also explain why there is such a gap between environmental knowledge and behavior. Surveys typically frame the environment in a positive manner as does most literature and that causes people to respond positively about their support for PEBs. But, when researchers reversed the framing and put PEB in a negative light, support for PEBs was much lower (Hiramatsu, Kurisu, \& Hanaki, 2015). This could imply that part of the gap in awareness and behavior is based on the fact that a percentage of those who present as if they care about environmental issues, may only be doing so because they believe that there is a descriptive norm that everyone should be willing to work to improve the environment.

It has also been demonstrated that people will engage in the default option because they assume it is the norm. To better illustrate this let's use the example of becoming an organ donor. Most places in the US allow people to opt in to becoming an organ donor when they sign up for a driver's license. Would that change if a person had to opt out of being an organ donor? In Europe, countries can use either method. In Denmark one must opt in and $4 \%$ do decide to be organ donors, but in Belgium you must opt out so $98 \%$ are registered donors. Neighbors Germany and Poland are similar: Germans must opt in, and they do so at $12 \%$. Poles must opt out and almost nobody does; $99.5 \%$ are registered organ donors (Johnson and Goldstein, 2003). There are nuances in the processes that may also influence how and why people donate, but Johnson and Goldstein found that even in their simulations, opt out situations had double the amount of donors as opt in situations. This was demonstrated more recently in a study at Disney hotels. Guests were asked to do their best to reuse towels; they could opt in (first choice) or they could opt out. Guests opted in at double the rate that they opted out (Baca-Motes, Brown, Gneezy, Keenan \& Nelson, 2013). Norming the desired behavior, by framing it as the default behavior, has been underused as a motivation for PEBs, but it appears successful when implemented.

\section{Rebellion as Motivation}

Rebellion against the status quo and corporatism in particular has been demonstrated to motivate individual behavior changes (Phelps 2009). This is particularly true for teenagers and young adults, who are carving out personal identities often in opposition to dominant social trends (Phelps, 2009; Pickard, 2009; Bryan et. al, 2016). In particular, this phenomenon has been studied in regards to eating habits, and teenagers were shown to be responsive to adopting vegetarian diets (Pickard, 2009) and making more healthy choices as rebellion against the norm of eating unhealthy (Bryan et. al, 2016). 
Healthy eating, vegetarianism, and veganism are often linked to counter culture movements (Belasco, 2007). Although the counterculture movement that grew in the 1960 s did not significantly change the dominant food industry, it did help create a counter industrial food movement that emphasizes organic, local, and humane food options (Belasco, 2007).

It is not only food that stirs the rebellious counter culture movement. Many within the environmental movement come from a place of rebellion against what they see as an unjust and uncaring system. Zelko (2013) demonstrates this side of the environmental movement by documenting the rebellious yet peaceful rise of Greenpeace. Activists putting their lives between the whaler and the whale are a way of rebelling against a cruel system that does not value non-human life (Zelko 2013).

Rebellion against a system, when paired with intelligent analysis of what one is rebelling against, can be useful in inciting positive change within a society that is not currently on a sustainable path. Research has demonstrated that rebellion has been a starting point for movements that create sustainable paths (Coglianese, 2001). "The (environmental) movement existed for much of the twentieth century as a small niche in American society, outside the mainstream of prevailing political discourse" (Coglianese, 2001). More research is required to understand what percentage of people who live "sustainable lifestyles" and engage in PEBs started from a place of rebellion. As environmentalists have become more mainstreamed and incorporated into government and corporate structures, they are no longer viewed as rebels or radicals. There have not been many attempts to frame rebellion as a way to encourage PEBs. However, environmental movement would not have existed without environmental rebels and extremists. Another group of environmental rebels may be necessary to push policy makers towards aggressively and effectively addressing climate change. The literature indicates that there is a segment of the population that would be motivated by communicating the rebellious and subversive nature of PEBs.

\section{Improved Happiness and Health as Motivation}

Research into PEBs has demonstrated that those that engage in PEBs have higher life satisfaction rates. "(M)ore frequent engagement in pro-environmental behaviors predicted higher life satisfaction" (Schmidt et al., 2018). It can be argued that many people who began engaging in PEBs did so because it brought them joy. The classic presentation of PEBs as a sacrifice that is necessary for the greater good may not always stand up to scrutiny. Many pro-environmental behaviors are high cost (Quimby and Angelique, 2011). It takes time to sort compost, recycling, and landfill/trash. Organic, grass-fed, freerange options can double or triple food costs. Pro-environmental transportation is sometimes inconvenient and limiting compared to driving a car. These costs in time, money, and convenience have led to the assumption that if people are not able to spend their time, money, and effort in a way that directly benefit their lives than this will negatively affect their well-being.

Happiness as a side effect of altruistic work has been called the "helper's high" (Post, 2005). Post (2005) argues that the literature in the field clearly demonstrates that people are happier when they are engaged in acts that benefit others, the benefits are not limited to personal happiness or self-reported wellbeing (SWB), there are significant health benefits that occur as well. This elevated feeling is not shortlived, it has long-term SWB effects as well (Corral-Verdugo, Mireles-Acosta, Tapia-Fonllem, \& FraijoSing, 2011).

The evidence for the long-term detrimental effects of fight or flight response is well established. There is an antidote to this effect:

"Altruistic emotions can gain dominance over anxiety and fear, turning off the fightflight response. Immediate and unspecified physiological changes may occur as a result of volunteering and helping others, leading to the so-called helper's high." (Post 2005, p. 71)

So it is plausible that there are people who are involved in PEBs for the "helper's high" that they receive for their service working for sustainability causes. It may not be altruism that keeps people 
involved in altruistic acts and PEBs; it may be that people are receiving benefits to both their health and happiness levels.

Anecdotal personal stories demonstrate that many people first got involved in sustainability and PEBs because they liked to mountain bike or camp or climb or hike. Others got involved because solar panels saved them money and they became interested in the issues. Fitbit and similar apps demonstrate that people like to receive direct feedback that shows they are improving their health, but there has been little study about combining these desires with sustainable action. Many sustainable lifestyle changes do increase health and happiness. Studies demonstrate that walking or biking to work increases self-reported well-being (Smith, 2017; Maus, 2013) while also decreasing an individual's carbon footprint. "Results in this study add further evidence that people who bike and walk to work are happier with their commutes and are relatively unaffected by traffic congestion compared to bus and car commuters" (Smith, 2017, p. 246). Having multi-modal transportation option including biking, walking, and public transportation increases self-reported well-being. (Makarewicz, C., \& Németh, J. 2017). Gardening is another act of sustainability with health and happiness as a side effect, especially for people over 60 (Van den Berg et al., 2010). Tying sustainability to an individual's health, wealth, and fitness is an underused and understudied area that appears to have the potential to motivate many people to engage in PEBs.

\section{FUTURE RESEARCH}

The information on what motivates PEBs is rich but fragmented. The disparate findings on motivations for PEBs demonstrate that people are motivated for a variety of reasons. The research across the social science spectrum indicates that those reasons can be roughly categorized into four areas. People who engage in PEBs for altruistic reasons are one group. Those that engage in PEBs because of social norming or perceived and real defaults would be another. Individuals who engage in PEBs due to rebellious or defiant motivations make up the third group. Finally, people who engage in PEBs for their own health or happiness compose the last group. A research question emerges: Do people roughly fall into one or several of these categories of motivation? It is unknown what percentages of people are actuated by each of these four motivations. It is also unclear if there is a relation between these motivations.

The complexities of psychology indicate that it would be unlikely for an individual to be exclusively and distinctly motivated by only one area of motivation, it is likely that certain motivations are more salient for certain individuals and certain groups. Testing individual to understand their proclivities could be helpful in the process of creating successful interventions to increase PEBs.

First a baseline must be established that explains the average saliency of each of these motivations and how demographic information correlates with saliency for each particular motivation. Building on that information, testing needs to be conducted that demonstrates the actual rate of effectiveness of using the intervention that focuses on a particular motivation. If there is a correlation between motivation saliency and intervention effectiveness then this information could lead to the creation of group specific interventions that are more effective at instigating personal change that increases PEBs. This information could be useful for government agencies and NGOs that are working to encourage PEBs.

There are some possible interventions available to test the veracity of these motivations. Altruism is a common motivation for those that engage in PEBs (Jones, 2014). Mindful meditation (MM) has been demonstrated to increase feelings of altruism (Raab, 2014). Mindful meditators are more likely to engage in PEBs. Using MM as an intervention strategy holds promise for increasing PEBs. For those that are motivated by social norms and defaults, PSAs (public service announcements) and articles could be created that frame PEBs as the norm and activities that are not pro-environmental as deviant. Exposure to these PSA as well as news and opinion articles could be used as an empirically testable intervention. A similar method could be used for those that identify with rebellion against the status quo as a motivation. This method is used in advertising aimed at a younger audience already. Creating an information stream that emphasizes the rebel qualities of PEBs could be used as an intervention to encourage PEBs. Framing PEBs as way to increase health or happiness is possibly the least studied motivational frame. Creating 
PSAs that encourage PEBs solely for their health and happiness effect (not including the environmental benefits at all) also has the ability to circumvent any political frame that views PEBs solely for the environment or the climate as unnecessary. These methods appear to hold much potential for increasing pro-environmental behaviors across the ideological spectrum, but rigorous empirical testing is needed before their effectiveness is proven.

\section{REFERENCES}

Baca-Motes, K., Brown, A., Gneezy, A., Keenan, E. A., \& Nelson, L. D. (2012). Commitment and behavior change: Evidence from the field. Journal of Consumer Research, 39(5), 1070-1084.

Bamberg, S., \& Möser, G. (2007). Twenty years after Hines, Hungerford, and Tomera: A new metaanalysis of psycho-social determinants of pro-environmental behaviour. Journal of environmental psychology, 27(1), 14-25.

Bauer, J. J., \& Wayment, H. A. (2008). The psychology of the quiet ego. In H. A. Wayment \& J. J. Bauer (Eds.), Transcending self-interest: Psychological explorations of the quiet ego (pp. 7-19). Washington, DC: American Psychological Association.

Belasco, W. (2007). Appetite for Change: How the Counterculture Took on the Food Industry. Cornell University Press. Retrieved from http://www.jstor.org/stable/10.7591/j.ctt5hh1rm

Bryan, C. J., Yeager, D. S., Hinojosa, C. P., Chabot, A., Bergen, H., Kawamura, M., \& Steubing, F. (2016). Harnessing adolescent values to motivate healthier eating. Proceedings of The National Academy Of Sciences Of The United States Of America, 113(39), 10830-10835. doi:10.1073/pnas.1604586113

Bush, G. (1990, February 5). Remarks to the Intergovernmental Panel on Climate Change. Online by Gerhard Peters and John T. Woolley, The American Presidency Project. Retrieved from http://www.presidency.ucsb.edu/ws/?pid=18117

California Air Resources Board (CARB) (2017, January 18). California's Advanced Clean Cars Midterm Review: Summary Report for the Technical Analysis of the Light Duty Vehicle Standards. (PDF). CARB, pp. ES 44. Retrieved January 19, 2017.

Cialdini, R. B., Kallgren, C. A., \& Reno, R. R. (1991). A focus theory of normative conduct: A theoretical refinement and reevaluation of the role of norms in human behavior. Advances in

experimental social psychology (Vol. 24, pp. 201-234). Academic Press.

Cialdini, R. B. (2003). Crafting normative messages to protect the environment. Current directions in psychological science, 12(4), 105-109.

Coglianese, C. (2001). Social movements, law, and society: The institutionalization of the environmental movement. University of Pennsylvania Law Review, 150(1), 85-118.

Corral-Verdugo, V., Mireles-Acosta, J. F., Tapia-Fonllem, C., \& Fraijo-Sing, B. (2011). Happiness as correlate of sustainable behavior: A study of pro-ecological, frugal, equitable and altruistic actions that promote subjective wellbeing. Human Ecology Review, 95-104.

Correa, A. J., \& Yildirim, H. (2016). "Giving” in to Social Pressure. Games \& Economic Behavior, 9999116. doi:10.1016/j.geb.2016.07.006

Clingingsmith, D. (2016). Negative emotions, income, and welfare: Causal estimates from the PSID. Journal of Economic Behavior \& Organization, 130, 1-19. ISSN 0167-2681. https://doi.org/10.1016/j.jebo.2016.07.004.

Davis, L. (2017). Evidence of a Decline in Electricity Use by U.S. Households. Retrieved from https://energyathaas.wordpress.com/2017/05/08/evidence-of-a-decline-in-electricity-use-by-u-shouseholds/

DeAngelis, T. (2004, June). Consumerism and its discontents. Retrieved March 30, 2018, from http://www.apa.org/monitor/jun04/discontents.aspx

Degenhardt, L. (2002) Why do People Act in Sustainable Ways? Results of an Empirical Survey of Lifestyle Pioneers. In Schmuck, P., \& Schultz, W. P. (Eds.). Psychology of sustainable development. Springer Science \& Business Media. 
DellaVigna, S., List, J.A., Malmendier, U. (2012) Testing for Altruism and Social Pressure in Charitable Giving. $Q J$ Econ, 127(1), 1-56. doi: 10.1093/qje/qjr050

DeSilver, D. (2015, November 17). How Americans are - and aren't-making eco-friendly lifestyle changes. Retrieved from http://www.pewresearch.org/fact-tank/2015/11/17/how-americans-areand-arent-making-eco-friendly-lifestyle-changes/

EIA. (2017) How much of U.S. energy consumption and electricity generation comes from renewable energy sources? Retrieved from https://www.eia.gov/tools/faqs/faq.php?id=92\&t=4

EIA. (2017, April 10). U.S. energy-related CO2 emissions fell 1.7\% in 2016. Retrieved from https://www.eia.gov/todayinenergy/detail.php?id=30712

EIA. (2017, June 14). Wind and solar in March accounted for 10\% of U.S. electricity generation for first time. Retrieved from https://www.eia.gov/todayinenergy/detail.php?id=31632

EIA. (2017, July 26). Per capita residential electricity sales in the U.S. have fallen since 2010. Retrieved from https://www.eia.gov/todayinenergy/detail.php?id=32212

EIA. (2018, March) Monthly Energy Review March 2018. Retrieved from https://www.eia.gov/totalenergy/data/monthly/pdf/sec1_5.pdf

EPA. (2017, November 21). Advancing Sustainable Materials Management: Facts and Figures. Retrieved from https://www.epa.gov/smm/advancing-sustainable-materials-management-facts-and-figures

Farrow, K., Grolleau, G., \& Ibanez, L. (2017). Social norms and pro-environmental behavior: A review of the evidence. Ecological Economics, 140, 1-13.

Fernandez, M., Piccolo, L., Alani, H., Maynard, D., Meili, C., \& Wippoo, M. (2017). Pro-Environmental Campaigns via Social Media: Analysing Awareness and Behaviour Patterns. The Journal of Web Science, 3(1)

Finger, M. (1994). From knowledge to action? Exploring the relationships between environmental experiences, learning, and behavior. Journal of social issues, 50(3), 141-160.

Forsythe, M. (2017, January 18). China Cancels 103 Coal Plants, Mindful of Smog and Wasted Capacity. Retrieved from https:/www.nytimes.com/2017/01/18/world/asia/china-coal-power-plantspollution.html

Gallup. (2018). Party Affiliation. Retrieved from http://news.gallup.com/poll/15370/party-affiliation.aspx

Gatersleben, B., Murtagh, N., \& Abrahamse, W. (2014). Values, identity and pro-environmental behaviour. Contemporary Social Science, 9(4), 374-392.

Geisler, C., \& Currens, B. (2017). Impediments to inland resettlement under conditions of accelerated sea level rise. Land Use Policy, 66, 322-330.

Gillis, A. J. (2016). Categorizing Pro-environmental Behaviors Using the Laypeople's Perspective. Retrieved from https://digitalcommons.unf.edu/cgi/viewcontent.cgi?article=1676\&context=etd

GOP. (2018). REPUBLICAN PLATFORM America's Natural Resources: Agriculture, Energy, and the Environment. Retrieved from https://www.gop.com/platform/americas-natural-resources/

Hiramatsu, A., Kurisu, K., \& Hanaki, K. (2015). Environmental consciousness in daily activities measured by negative prompts. Sustainability, 8(1), 24.

Jacob, J., Jovic, E., \& Brinkerhoff, M. B. (2009). Personal and planetary well-being: Mindfulness meditation, pro-environmental behavior and personal quality of life in a survey from the social justice and ecological sustainability movement. Social Indicators Research, 93(2), 275-294.

Johnson, E., \& Goldstein, D. (2003). Do Defaults Save Lives? Science, 302(5649), 1338-1339. Retrieved from http://www.jstor.org.libproxy.nau.edu/stable/3835592

Jones, R. G. (2014). Psychology of sustainability: an applied perspective. Routledge.

Kao, C.H., Su, J.C., \& Crocker, J., et al. (2017). J Happiness Study, 18, 959. Retrieved from https://doiorg.libproxy.nau.edu/10.1007/s10902-016-9759-4

Kollmuss, A., \& Agyeman, J. (2002). Mind the gap: why do people act environmentally and what are the barriers to pro-environmental behavior? Environmental education research, 8(3), 239-260.

Kurisu, K. (2015). Pro-environmental behaviors. Tokyo: Springer Japan. 
Lakoff, G. (2010). Why it matters how we frame the environment. Environmental Communication, 4(1), 70-81. doi:10.1080/17524030903529749

Leahy, S. (2017, May 22). India Launches Massive Push for Clean Power, Lighting, and Cars. Retrieved from http://news.nationalgeographic.com/2017/05/india-solar-wind-renewable-power-electriccars-leds/

Lipka, M., \& Gecewicz, C. (2017, September 06). More Americans now say they're spiritual but not religious. Retrieved from http://www.pewresearch.org/fact-tank/2017/09/06/more-americansnow-say-theyre-spiritual-but-not-religious/

Makarewicz, C., \& Németh, J. (2017). Are multimodal travelers more satisfied with their lives? A study of accessibility and wellbeing in the Denver, Colorado metropolitan area. Cities, 74, 179-187.

Markowitz, E. M., Goldberg, L. R., Ashton, M. C., \& Lee, K. (2012). Profiling the 'Pro-Environmental Individual': A Personality Perspective. Journal of Personality, 80(1), 81-111. doi:10.1111/j.14676494.2011.00721.

Marshall, G. (2015). Don't even think about it: Why our brains are wired to ignore climate change. Bloomsbury Publishing USA.

Masud, M. M., Al-Amin, A. Q., Junsheng, H., Ahmed, F., Yahaya, S. R., Akhtar, R., \& Banna, H. (2016). Climate change issue and theory of planned behaviour: relationship by empirical evidence. Journal of Cleaner Production, 113, 613-623.

Maus, J. (2013) Bike commuters are happiest (and other PSU research tidbits). Retrieved from https://bikeportland.org/2013/01/30/bike-commuters-are-happiest-and-other-psu-research-tidbits82448?utm_source=feedburner\&utm_medium $=$ feed\&utm_campaign=Feed $\% 3 \mathrm{~A}+$ BikePortland + $\% 28$ BikePortland.org\%29

McDonald, C. (2015, June 16). How many Earths do we need? Retrieved from http://www.bbc.com/news/magazine-33133712

Micklin, P. (2007). The Aral sea disaster. Annu. Rev. Earth Planet. Sci., 35, 47-72.

Navarrete, C.D., et al. (n.d.). Fear is readily associated with an out-group face in a minimal group context. Evolution and Human Behavior, 33(5), 590 - 593.

Nerem, R. S., Beckley, B. D., Fasullo, J. T., Hamlington, B. D., Masters, D., \& Mitchum, G. T. (2018). Climate-change-driven accelerated sea-level rise detected in the altimeter era. Proceedings of the National Academy of Sciences, 201717312.

Nickerson, R. S. (1998). Confirmation bias: A ubiquitous phenomenon in many guises. Review of general psychology, 2(2), 175.

NOAA. (2017) Gulf of Mexico 'dead zone' is the largest ever measured June outlook foretold New Jersey-sized area of low oxygen Retrieved from http://www.noaa.gov/media-release/gulf-ofmexico-dead-zone-is-largest-ever-measured

Nyhan, B., \& Reifler, J. (2010). When corrections fail: The persistence of political misperceptions. Political Behavior, 32(2), 303-330.

Obradovich, N., \& Guenther, S. M. (2016). Collective responsibility amplifies mitigation behaviors. Climatic change, 137(1-2), 307-319.

Ozinga, J.R. (1999) Altruism. Westport, CT, Praeger Publishers.

Perry, M. (2014) Today's new homes are 1,000 square feet larger than in 1973, and the living space per person has doubled over last 40 years. Retrieved from http://www.aei.org/publication/todaysnew-homes-are-1000-square-feet-larger-than-in-1973-and-the-living-space-per-person-hasdoubled-over-last-40-years/

Pew Research Center. (2014) Growing Public Support for Gun Rights. Retrieved from http://www.people-press.org/2014/12/10/growing-public-support-for-gun-rights/

Pew Research Center. (2017) Top Voting Issues in 2016 Election. Retrieved from http:/www.peoplepress.org/2016/07/07/4-top-voting-issues-in-2016-election/

Pew Research Center. (2017) Support for Same-Sex Marriage Grows, Even Among Groups That Had Been Skeptical. Retrieved from http://www.people-press.org/2017/06/26/support-for-same-sexmarriage-grows-even-among-groups-that-had-been-skeptical/ 
Phelps, E.S. (2009). CAPITALISM VS. CORPORATISM. Critical Review, 21(4), $401-414$.

Pickhardt, C.E. (2009, December 6). Dr. Rebel with a Cause: Rebellion in Adolescence. Psychology Today. Retrieved from https://www.psychologytoday.com/us/blog/surviving-your-childsadolescence/200912/rebel-cause-rebellion-in-adolescence

Plumer, B. (2017, June 27). The Origins of Anti-Litter Campaigns. Retrieved from https://www.motherjones.com/politics/2006/05/origins-anti-litter-campaigns/

Post, S.G. (2005) Altruism, Happiness, and Health: It's Good to be Good. International Journal of Behavioral Medicine, p.66-77.

Quealy, K. (2017, November 14). The More Education Republicans Have, the Less They Tend to Believe in Climate Change. New York Times. Retrieved from https://www.nytimes.com/interactive/2017/11/14/upshot/climate-change-byeducation.html? $\mathrm{rref}=$ collection/sectioncollection/climate\&action $=$ click\&contentCollection $=$ clima te ${ }^{\circledR}$ ion $=$ stream\&module $=$ stream_unit\&version=latest\&contentPlacement $=2 \&$ pgtype $=$ sectionfront \&login=email

Quimby, C., \& Angelique, C. (2011). Identifying Barriers and Catalysts to Fostering Pro-Environmental Behavior: Opportunities and Challenges for Community Psychology. American Journal of Community Psychology, 47(3), 388-396.

Raab, K. (2014). Mindfulness, self-compassion, and empathy among health care professionals: a review of the literature. Journal of health care chaplaincy, 20(3), 95-108.

Rabotyagov, S. S., Kling, C. L., Gassman, P. W., Rabalais, N. N., \& Turner, R. E. (2014). The economics of dead zones: Causes, impacts, policy challenges, and a model of the Gulf of Mexico hypoxic zone. Review of Environmental Economics and Policy, 8(1), 58-79.

RE100. (2018) The world's most influential companies, committed to 100\% renewable power. Retrieved from http://there100.org/re100

Reyniers, D., \& Bhalla, R. (2013). Reluctant altruism and peer pressure in charitable giving. Judgment \& Decision Making, 8(1), 7-15.

Rivis, A., \& Sheeran, P. (2003). Descriptive norms as an additional predictor in the theory of planned behaviour: A meta-analysis. Current Psychology, 22(3), 218-233.

Schmitt, M. T., Aknin, L. B., Axsen, J., \& Shwom, R. L. (2018). Unpacking the relationships between pro-environmental behavior, life satisfaction, and perceived ecological threat. Ecological Economics, 143, 130-140.

Schultz, P. W., Nolan, J. M., Cialdini, R. B., Goldstein, N. J., \& Griskevicius, V. (2007). The constructive, destructive, and reconstructive power of social norms. Psychological science, 18(5), 429-434.

Stern, P. C., Dietz, T., Abel, T.D., Guagnano, G.A., (1999). A Value-Belief-Norm Theory of Support for Social Movements: The Case of Environmentalism. Human Ecology Review, 6(2), 81 - 97. Retrieved from: http://works.bepress.com/troy_abel/3/

Steg, L., \& Vlek, C. (2009). Encouraging pro-environmental behaviour: An integrative review and research agenda. Journal of environmental psychology, 29(3), 309-317.

Storrow, B., E\&E News, \& E\&E Daily. (n.d.). STATES: New best friends: GOP governors and renewables. Retrieved from https://www.eenews.net/stories/1060056498

Tkacz \& Moore. (2014) CONGREGATIONS AND ALL GOD'S CREATURES. Retrieved from https://digitalcommons.kent.edu/acir/2014/Three/10/

Terry, D. J., Hogg, M. A., \& White, K. M. (1999), The theory of planned behaviour: Self-identity, social identity and group norms. British Journal of Social Psychology, 38, 225-244. doi:10.1348/01446669916414

Truelove, H. B., Carrico, A. R., Weber, E. U., Raimi, K. T., \& Vandenbergh, M. P. (2014). Positive and negative spillover of pro-environmental behavior: An integrative review and theoretical framework. Global Environmental Change, 29, 127-138.

UNCC. (2017). The Paris Agreement. Retrieved from https://unfccc.int/process/the-paris-agreement/theparis-agreement 
UNEP. (2016). The Emissions Gap Report 2016 - Executive summary. Retrieved from http://wedocs.unep.org/bitstream/handle/20.500.11822/10572/EGR_Executive\%20_summary_E N.pdf? sequence $=1 \&$ isAllowed $=\mathrm{y}$

Unsworth, K. L., \& McNeill, I. M. (2017). Increasing pro-environmental behaviors by increasing selfconcordance: Testing an intervention. Journal of Applied Psychology, 102(1), 88.

US Global Change Research Program. (2009). Global climate change impacts in the United States. Cambridge University Press.

Van den Berg, A. E., van Winsum-Westra, M., De Vries, S., \& Van Dillen, S. M. (2010). Allotment gardening and health: a comparative survey among allotment gardeners and their neighbors without an allotment. Environmental Health, 9(1), 74.

Vicente-Molina, M. A., Fernández-Sáinz, A., \& Izagirre-Olaizola, J. (2013). Environmental knowledge and other variables affecting pro-environmental behaviour: comparison of university students from emerging and advanced countries. Journal of Cleaner Production, 61, 130-138.

Victor, D. G., Obradovich, N., \& Amaya, D. J. (2017, September 18). Why the wiring of our brains makes it hard to stop climate change. Retrieved from https://www.brookings.edu/blog/planetpolicy/2017/09/18/why-the-wiring-of-our-brains-makes-ithard-to-stop-climate-change/

Villagra, N., \& López, B. (2013). Analysis of values and communication of the Responsible Brands. Corporate Brand strategies for sustainability. Comunicación Y Sociedad, 26(1), 197-222

Wayment, H.A., Bauer, J.J., \& Sylaska, K. J. (2015). The Quiet Ego Scale: Measuring the Compassionate Self-Identity Happiness Study, 16, 999. doi:10.1007/s10902-014-9546-Z

World Bank. (2015). CO2 emissions (metric tons per capita). Retrieved 2018, from https://data.worldbank.org/indicator/EN.ATM.CO2E.PC?locations=US\&year_high_desc=true

Xiaodong, C., Lupi, F., Guangming, H., \& Jianguo, L. (2009). Linking social norms to efficient conservation investment in payments for ecosystem services. Proceedings of The National Academy of Sciences Of The United States Of America, 106(28), 11812-11817. doi:10.1073/pnas.0809980106

Xie, J., Sreenivasan, S., Korniss, G., Zhang, W., Lim, C., Szymanski, B. (2011). Social consensus through the influence of committed minorities. Physical Review E, 84(1). DOI:10.1103/PhysRevE.84.011130

Xu, Y., Wu, Y., Han, J., \& Li, P. (2017). The current status of heavy metal in lake sediments from China: Pollution and ecological risk assessment. Ecology and evolution.

Young, W., Davis, M., McNeill, I. M., Malhotra, B., Russell, S., Unsworth, K., \& Clegg, C. W. (2015). Changing behaviour: successful environmental programmes in the workplace. Business Strategy and the Environment, 24(8), 689-703.

Zelko, F. (2013) Make It a Green Peace! The Rise of Countercultural Environmentalism. New York: Oxford University Press. 